\title{
A Missa Afro: Possibilidades de enfrentamento do racismo no Brasil
}

Luiz Ernesto Guimarães ${ }^{\mathrm{a}}$

Este artigo analisa em uma paróquia na região norte do Paraná como atores católicos desenvolvem a partir da missa afro espaços de luta e enfrentamento ao racismo no Brasil. Apesar de haver resistências por parte do clero e também de muitos fieis, a formulação desse ritual busca trazer para os católicos a conscientização sobre a realidade em que vive o negro no país ainda hoje, ao ocupar posições subalternas em diversas esferas da sociedade. Embora haja limites em alcançar tal objetivo, a missa afro demonstra-se um elemento concreto da continuidade da Teologia da Libertação na atualidade.

Missa afro; Catolicismos; Racismo; Teologia da Libertação; Religião e política.

Neste artigo analiso a abordagem sobre a questão racial desenvolvida por membros do clero e leigos na paróquia Nossa Senhora dos Migrantes, limítrofe ente os municípios de Cambé e Londrina, região norte do Paraná. A missa afro, realizada semestralmente, é o espaço principal onde é desenvolvida a reflexão sobre o negro no contexto brasileiro. $\mathrm{O}$ presente estudo é formulado a partir das contribuições da etnografia, com a participação nesses ritos nos anos de 2015 e 2016. Foram também realizadas entrevistas com roteiro semiestruturado com alguns agentes envolvidos nesses eventos.

a Professor do Departamento de Ciências Humanas da UEMG - Barbacena. Email: pr.ernesto@gmail.com. 
A abordagem sobre a questão racial no catolicismo está de certa maneira associada às lutas formuladas pelo movimento negro no Brasil. Nesse sentido, a influência da Teologia da Libertação é significativa, pois "todos os movimentos sociais, incluído o dos negros, lutam pela justiça social e por uma redistribuição equitativa do produto coletivo" (Munanga 2006:13). A formulação desses rituais é percebida, portanto, como extensão do movimento negro, exigindo dos atores certa habilidade na organização e articulação desses eventos religiosos e políticos, por não contar com apoio expressivo das hierarquias católicas, bem como da maioria dos fieis, resistentes a tais eventos.

Esse ritual expressa a tentativa de desenvolver nos fieis a conscientização sobre a importância do negro na formação da sociedade brasileira, começando com a escravidão na primeira metade do século XVI. Nesse sentido, assim como os movimentos negros atuam na construção dessa reflexão, há na missa afro certas semelhanças, como a análise de

"seu passado histórico como herdeiros dos escravizados africanos, sua situação como membros de grupo estigmatizado, racializado e excluído das posições de comando na sociedade cuja construção contou com seu trabalho gratuito, como membros de grupo étnico-racial que teve sua humanidade negada e a cultura inferiorizada" (Munanga 2006:14).

De acordo com o antropólogo de origem africana, Kabemgele Munanga, "essa identidade passa por sua cor, ou seja, pela recuperação de sua negritude, física e culturalmente” (Munanga 2006:14). Se no âmbito do movimento negro a tarefa tem exigido inúmeros esforços, como reconhece o antropólogo, no sentido de conseguir ampla mobilização da população negra, no caso da Teologia da Libertação, que busca refletir e conscientizar os fieis sobre esses mesmos elementos, percebe-se também alguns obstáculos na realização da missa afro.

Um dos problemas encontrados pelo movimento negro e, portanto, também por esses eventos católicos, estão associados à ideologia racial de branqueamento entre o final do século XIX e meados do sé- 
culo XX: "Apesar do processo de branqueamento físico da sociedade ter fracassado, seu ideal inculcado através de mecanismos psicológicos ficou intacto no inconsciente coletivo brasileiro, rodando sempre nas cabeças dos negros e mestiços” (Munanga 2006:16). Isso, para o autor, prejudica qualquer forma de desenvolvimento da identidade negra, pois existe o desejo de alcançar a identidade branca, apresentada como superior pelas elites brasileiras. Assim, Kabemgele Munanga (2006) afirma que as dificuldades da mobilização dos negros estão ligadas ao fato de ainda hoje não conseguir superar totalmente os efeitos resultantes do processo de eugenia no país.

Não obstante a isso, os enfrentamentos do movimento negro demonstra certa esperança de superação dos resquícios que tal ideologia deixou no Brasil. No caso de setores do catolicismo, que buscam problematizar a questão racial, isso também se aplica, tornando assim uma forma de resistência na atualidade na luta contra o racismo, bem como uma extensão do movimento negro nos quadros da instituição católica, especialmente setores que se orientam pelo viés da Teologia da Libertação, onde é possível o desenvolvimento de ações que contribuam para a superação das discriminações raciais.

Neste estudo da missa afro, a abordagem da prática, como Sherry Ortner (2011) a formula, permite compreender como estrutura e agência estão interligadas, rompendo dessa forma com o objetivismo e o subjetivismo presentes na teoria antropológica. $\mathrm{O}$ ator social possui em suas ações aspectos subjetivos, mas que, no entanto, não se encontram alheios à estrutura da qual está inserido. Assim, a luta contra o racismo e a discriminação no interior da Igreja Católica não pode ser compreendida sem a existência de forças que atuam sobre tais agentes, resultando no surgimento de certos limites na prática social.

\section{O negro em Londrina}

A história do negro em Londrina assemelha-se a alguns aspectos ocorridos em outras cidades brasileiras: a sua invisibilidade como for- 
ma de branqueamento da população (Silva 2008b). Assim, sua presença é ocultada. De acordo com Maria Nilza da Silva, "a história oficial da cidade de Londrina, não menciona a presença da população negra no processo de colonização" (Silva 2008a:4).

Em uma coletânea de textos organizados por Fabio Lanza ${ }^{1}$, a presença negra em Londrina é descrita dessa maneira:

“A versão oficial da história de Londrina, à qual temos acesso nos museus, livros e escolas, não valorizou a contribuição dos trabalhadores pioneiros e suas famílias. Eles não receberam destaque ou reconhecimento público, o que comumente acontece com as famílias daqueles que possuíam muitas terras e dinheiro, e que até hoje tem seus nomes louvados em praças, ruas e escolas. No caso das famílias negras, os trabalhadores e trabalhadoras também são anônimos e duplamente desprestigiados, porque eram explorados como mão de obra dentro da lógica econômica capitalista e também discriminados pelo preconceito racial presente na sociedade brasileira" (Lanza 2013:20).

A formação de Londrina, no contexto da região norte do Paraná, realizada entre o final da década de 1920 e início de 1930, é resultado de uma recente colonização, "baseada em um empreendimento capitalista racional, com capital inglês associado ao capital nacional, comandado pela Companhia de Terras Norte do Paraná - CTNP" (Almeida 2009:1).

Esse projeto colonizador da CTNP tornou-se "um empreendimento imobiliário dos mais lucrativos, atraindo migrantes nacionais e estrangeiros que buscavam terras férteis e baratas para o desenvolvimento da agricultura" (Almeida 2009:1). Rapidamente Londrina transformou-se em um importante polo econômico da região, com intenso processo de urbanização e a principal característica de prestação de serviços, conforme destaca Ana Maria Chiarotti de Almeida (2009).

Desde o início do processo de colonização até a década de 1960 o crescimento econômico e demográfico da região foi surpreendente (Padis 1981), havendo um verdadeiro rush populacional. Eram traba- 
lhadores interessados na agricultura, especialmente na produção do café, atraídos pelo valor mais acessivel dessas terras. "Esse fluxo era constituído principalmente de paulistas - ainda provindos das regiões de Campinas, São Carlos e Ribeirão Preto - e de mineiros, mas também, de migrantes vindos de outras partes do País - especialmente o Nordeste - e até de estrangeiros" (Padis 1981:93).

A diversidade étnica pela qual Londrina se desenvolveu é destacada: quinze anos após sua fundação, a cidade era formada em 1945 por pessoas de "trinta nacionalidades diferentes sendo 12,5 por cento italianos, 7 por cento japoneses, 6 por cento alemães, além de 42 por cento entre paulistas e mineiros" (Padis 1981:93).

Dessa maneira, "foi assim que a região Norte do Paraná passou a ser denominada entre as décadas de 1940 e 1960 de 'Eldorado', 'Terra de Canaã' e a cidade de Londrina considerada 'Capital Mundial do Café"” (Almeida 2009:2).

A diversidade étnica presente na formação da cidade e a região norte do Paraná é, portanto, significativa. No entanto, a população negra, uma das integrantes nesse processo de construção de Londrina, é retirada intencionalmente da história oficial, dando lugar apenas à figura do imigrante europeu, silenciando a existência dessa população, juntamente com a indígena ${ }^{2}$ (Silva 2008a).

Ana Maria Chiarotti de Almeida defende que há na história oficial e na memória sobre a cidade "um discurso apologético do papel da CTNP e dos ingleses na colonização e ocupação do território, emergindo como personagem principal a figura do 'pioneiro' - sentido atribuído para quem primeiro desbravou a mata virgem e transformou a terra bruta em 'ouro verde' (o café)" (Almeida 2009:2). Sobre isso a cientista social continua sua análise:

"Na realidade, existe uma tendência nas iniciativas oficiais de registro e preservação da memória local e regional em afirmar o mito fundador na região pela CTNP, reproduzindo um discurso que confere notabilidade à própria companhia e aos grupos hegemônicos do processo. Mais do que isso, ao reproduzir o discurso apologético e celebrativo da colonização reafirma-se o sentido épico e heroico do 
pioneiro, instaurando um processo de silenciamento de grupos e populações que também tiveram importância na ocupação da cidade e região, a exemplo dos trabalhadores urbanos e rurais - aqui incluída a população negra muito utilizada nas lavouras do café em outros Estados do Brasil que migraram para a região - os pequenos produtores de café, antigos migrantes estrangeiros e trabalhadores das fazendas de café de São Paulo e Minas Gerais e que, normalmente, são pouco lembrados pelo poder público em suas ações de registro da memória" (Almeida 2009:2,3).

Enquanto a população negra é silenciada, outros grupos que também contribuíram para a formação da cidade ganham visibilidade na história bem como na vida cotidiana, ao observar os espaços públicos construídos com objetivo de homenageá-los ${ }^{3}$. Já para a população negra não existe nada nesse sentido, o que é alvo de diversas críticas por parte do movimento negro que atua em Londrina.

O que se deseja evidenciar ou ocultar, lembrar ou esquecer, está presente nas relações de poder, fazendo com que a memória coletiva esteja em jogo de forma permanente, por diversos grupos, na luta por capital cultural e poder simbólico (Almeida 2009).

Maurice Halbwachs (2004) ao desenvolver o conceito de memória coletiva o faz a partir do viés metodológico formulado por Émile Durkheim, onde os fatos sociais devem ser tratados como coisa. Nessa tradição sociológica a "ênfase é dada à força quase institucional dessa memória coletiva, à duração, à continuidade, à estabilidade" (Pollak 1989:3). Assim, essa força atua em diferentes pontos de referência de forma a estruturar a memória do indivíduo àquelas da coletividade da qual pertence. Michael Pollak destaca como exemplo os monumentos, o patrimônio arquitetônico, as paisagens, datas comemorativas e personagens históricos, além das tradições, costumes, folclore, música e culinária.

Esses diferentes pontos de referência podem ser tomados como "indicadores empíricos da memória coletiva de um determinado grupo, uma memória estruturada com suas hierarquias e classificações, uma memória também que, ao definir o que é comum a 
um grupo e o que, o diferencia dos outros, fundamenta e reforça os sentimentos de pertencimento e as fronteiras socioculturais" (Pollak 1989:3).

Nessa corrente de pensamento a memória coletiva é percebida como única possível, além de carregar a ideia de nação e nacionalismo (Pollak 1989; Tomazi 2000), como expressão mais definida de sociedade. Nelson Dacio Tomazi ao pesquisar as histórias e fantasmagorias que permeiam a expressão 'Norte do Paraná'4, afirma: "Transpondo este raciocínio para a análise regional poder-se-ia afirmar que, nesta perspectiva, há a construção de uma determinada memória histórica que visa a coesão social e basicamente a manutenção da situação vigente" (Tomazi 2000:28).

De acordo com Tomazi (2000), a história escrita a partir de grupos dominantes se perpetua de forma homogênea, conforme o conceito de poder simbólico cunhado por Pierre Bourdieu: "um poder de construção da realidade que tende a estabelecer uma ordem gnosiológica: o sentido imediato do mundo (e, em particular do mundo social) supõe aquilo a que Durkheim chama o conformismo lógico, quer dizer uma concepção homogênea do tempo, do espaço, do número, da causa, que torna possível a concordância entre as inteligências” (Bourdieu 1989:11).

O cientista social francês, seguindo a tradição marxista, afirma que "as ideologias, por oposição ao mito, produto coletivo e coletivamente apropriado, servem interesses particulares que tendem a apresentar como interesses universais, comuns ao conjunto do grupo" (Bourdieu 1989:10). Assim, a história oficial de Londrina, ao silenciar a população negra, que também participou de sua construção, contribui para a formação de sistemas simbólicos "que se constituem em verdadeiros instrumentos de legitimação da dominação” (Tomazi 2000:29).

Bourdieu (1989) ressalta que a cultura dominante contribui de duas formas distintas: a) para a integração real da classe dirigente e b) para a desmobilização das classes dominadas, por meio da falsa consciência. Permite também para que haja a "legitimação da ordem 
estabelecida por meio do estabelecimento das distinções (hierarquias) e para a legitimação dessas distinções” (Bourdieu 1989:10). Jacques Le Goff também percebe as relações de poder presentes na construção da memória coletiva: "tornar-se senhores da memória e do esquecimento é uma das grandes preocupações das classes, dos grupos, dos indivíduos que dominaram e dominam as sociedades históricas" (2003:422).

Assim, "os esquecimentos e silêncios da história podem nos dizer muito sobre como e de que forma a memória coletiva foi ou tem sido manipulada para atingir certos objetivos de classes e de grupos hegemônicos" (Almeida 2009:3).

No entanto, se para Maurice Halbwachs (2004) a memória coletiva se assenta na perspectiva da estabilidade e coesão social, Michael Pollak (1989) destaca outro viés, onde existe o interesse pelos "processos e atores que intervêm no trabalho de constituição e de formalização das memórias" (Pollak 1989:4). Assim, a memória coletiva deixa de ser percebida de uma única maneira, tornando-se muitas memórias coletivas (Tomazi 2000).

Nessa concepção, ao privilegiar grupos excluídos, marginalizados e silenciados pela memória oficial, contribui para ressaltar e valorizar o que Pollak denomina de memórias subterrâneas que, "como parte integrante das culturas minoritárias e dominadas, se opõem à 'Memória oficial"" (Pollak 1989:4), pensando enquanto memória nacional. No entanto, isso pode ser aplicado a um contexto local, como o norte do Paraná, que, a seu modo, desenvolveu uma memória coletiva 'regional', a partir da seleção de alguns grupos, em detrimento e silenciamento de outros, como a população negra.

Ao partir desse pressuposto, percebe-se o espaço social enquanto "campo de forças ou um conjunto de relações de poder, onde se trava a luta concorrencial entre os atores e grupos em torno de interesses específicos" (Almeida 1997:83). Ao discutir Bourdieu, a autora defende que, da mesma forma como existe um jogo pela disputa dos bens econômicos, há também a configuração de forças no âmbito simbó- 
lico que contribui para a determinação da posição social de grupos e classes, que para Almeida (1997) é a lógica da distinção.

Ao fazer essa abordagem, em que o espaço social é permeado por lutas entre diversos agentes e grupos sociais, não somente proporciona novas análises a partir de setores subalternizados e 'esquecidos' no processo histórico de dominação, mas também contribui para o estabelecimento sistemático de suas ações, o que Ana Maria Chiarotti de Almeida denomina de memória dos coadjuvantes, "demonstrando as microrrelações e os espaços 'intersticiais' criados no cotidiano e relacionados a processos sociais mais amplos” (Almeida 2009:4).

Há, portanto, em Londrina, atores sociais que historicamente vêm buscando formas de romper com o discurso oficial de valorização do imigrante europeu branco que, por sua vez, gera o esquecimento e retirada dos negros da história da construção da cidade. Idalto José de Almeida (2004) aborda desde a década de 1930, época da oficialização da cidade enquanto município, personagens e espaços voltados para os negros na cidade 5 .

Nessa primeira década de formação da cidade, chegou à Londrina Manoel Cypriano, negro, oriundo de Campinas para trabalhar como motorista particular de Arthur Thomas ${ }^{6}$, pela Companhia de Terras Norte do Paraná e "aos poucos foi escrevendo as primeiras linhas da história da presença negra na cidade” (Almeida 2004:25).

$\mathrm{Na}$ época, por ser proibida a entrada de negros em clubes da cidade, como o Country, Manoel Cypriano foi um dos responsáveis pela criação de um espaço próprio para que o negro pudesse participar. Afinal, "enquanto a elite da sociedade londrinense constituía seus espaços socais próprios, inclusive étnicos, grande parte da população via-se excluída, provocando uma demanda social reprimida, principalmente para a população afrodescendente" (Almeida 2004:26).

De acordo com Almeida (2004), na década de 1940 em oposição ao 'clube do Redondo', pertencente à elite londrinense, Cypriano contribuiu para a formação do 'clube do Quadrado', com intuito de abrigar a população excluída desses espaços. Posteriormente passou a 
chamar-se Associação Princesa Isabel, sem a devida crítica ao processo de abolição da escravatura que contou amplamente com a participação da população negra.

Sem poder contar com sede própria, Cypriano utilizava sua própria casa para fazer as reuniões, além de bailes e festas. Em 1952 a Associação Princesa Isabel foi oficializada, com objetivo de desenvolver atuação em questões sociais e recreativas. Havia também uma espécie de ajuda mútua entre os participantes, como forma de resolver alguns problemas enfrentados pelos membros da entidade. Sobre isso, Almeida afirma: "se alguém precisava de ajuda por algum motivo de doença, ou mesmo para a compra de material escolar para os filhos, todos contribuíam". Continua o autor: "Além disso, frequentemente eram promovidas conferências para se debater as questões relacionadas ao racismo" (Almeida 2004:26).

Assim, em decorrência do crescimento da população negra em Londrina e a demanda por espaços para atender a esse segmento que era excluído, resultou em 1956 na formulação da AROL - Associação de Recreação Operária Londrinense. Um clube como forma de desdobramento das organizações lideradas por Cypriano até então, como a Associação Princesa Isabel. Naquele momento já havia grupos com caráter étnico, como a AREL - Associação Recreativa e Esportiva de Londrina, que atendia aos imigrantes alemães e a ACEL - Associação Cultural e Esportiva de Londrina, frequentada por japoneses (Almeida 2004). Assim, a AROL foi presidida primeiramente por Cypriano, buscando atender a população negra, cuja entrada em outros clubes era proibida.

A contribuição de Cypriano na formulação e liderança da AROL foi tão significativa que com a sua morte em agosto de 1964, as atividades da entidade foram afetadas e aos poucos começaram a arrefecer (Silva 2008b). As festas e eventos começaram a diminuir ao mesmo tempo em que o novo prefeito, Hosken de Novaes, foi aos poucos retirando o apoio da gestão anterior, de Antônio Fernandes Sobrinho, grande incentivador da AROL (Almeida 2004). Além do mais, a As- 
sociação dependia de um dirigente que pudesse ter tempo suficiente para ficar à sua disposição, como fazia Cypriano. Com sua morte, não houve um sucessor com o mesmo perfil, sendo outro elemento que contribuiu para o seu fim.

Assim, a história de Manoel Cypriano e da AROL se confundem no contexto da luta da população negra em Londrina, não somente contra o preconceito, mas também contra os processos de silenciamento que também estavam presentes na valorização de um grupo em seu detrimento.

No processo de organização de reflexões a favor dos negros em Londrina, no campo religioso se destaca Vilma Santos de Oliveira (1950 - 2013), ou dona Vilma, como era chamada. Sua inserção no candomblé deu-lhe o nome de Yá Mukumbi. Nascida em Jacarezinho, cidade a 155 quilômetros de Londrina, em julho de 1950, era negra e de família pobre, era filha de mãe paulista e pai mineiro, que vieram para o Paraná em busca de trabalho no setor açucareiro, forte na região naquela época. Perdeu o pai quando tinha apenas onze dias de vida, passando à mãe toda a responsabilidade de sua criação. Em 1951 muda-se para Londrina, a convite do tio Leodoro que contribuiu para o início da cidade, com a derrubada de árvores e vendas de lotes, assim como tantos outros negros (Lanza 2013).

Seu contato com o movimento negro em Londrina iniciou logo cedo. A casa onde morava em Londrina ficava ao lado da AROL, além de que seu tio Leodoro, juntamente com Manoel Cypriano, contribuíram para a primeira organização de negros na cidade ainda em formação. Conforme observa Lanza (2013), ainda cedo iniciou sua militância política ao participar do movimento estudantil, frequentando as reuniões da União Londrinense de Estudantes Secundaristas - ULES. Por ser no período da ditadura militar, o tio, receoso sobre a possibilidade de haver retaliações, impediu sua participação de forma mais efetiva.

Adepta do Candomblé, dona Vilma teve contato, primeiramente, com o Espiritismo, por motivos de saúde na adolescência, passando 
posteriormente a frequentar a Umbanda. Depois, por intermédio de uma tia, conheceu o Candomblé, cuja identificação fez com que permanecesse nessa religião de matriz africana. Aos 26 anos tornou-se mãe de santo. Em Cambé construiu sua casa de Candomblé nomeada Ilé Ashé Ogum Mêge, construída na década de 1970, sendo uma das mais antigas da região. Nessa casa "são realizados vários projetos socioeducacionais e culturais, cujo principal objetivo é promover a cidadania e a preservação da cultura afro-brasileira, atingindo principalmente os grupos populacionais marginalizados e discriminados" (Lanza 2013:30).

A trajetória de dona Vilma na religião do Candomblé confundese também com seu envolvimento político em Londrina, especialmente em assuntos relacionados à questão racial. Embora a AROL tenha fechado em 1981, foi importante em sua compreensão da situação do negro no Brasil. Isso se desenvolveu em sua Casa de Candomblé em Cambé, onde o engajamento em defesa da população negra era evidente. Dona Vilma participou primeiramente do grupo União e Consciência Negra e depois se juntou ao movimento negro de Londrina (Lanza 2013).

Junto a isso, na década de 1980 deu outro passo que demonstra a proximidade em que religião e política foram elementos complementares em sua trajetória, ao filiar-se ao PT, lugar onde encontrou espaço para a ampliação de sua reflexão e engajamento em favor dos negros. Tudo isso fez com que dona Vilma, "a Mãe de Santo, conquistasse visibilidade e passasse a ser conhecida e respeitada pela sociedade londrinense envolvida com o debate político e racial" (Lanza 2013:32).

Dona Vilma também participou ativamente das discussões sobre ações afirmativas, especialmente com a implementação de cotas raciais na Universidade Estadual de Londrina, iniciado no vestibular de 2005 (Silva 2008b) e que tem permitido a inserção de estudantes no ensino superior público como forma de democratização da educação ${ }^{7}$. Até então, o público de estudantes da UEL era majoritariamente composto por brancos, sendo muitos oriundos de outros estados, sobretudo, São 
Paulo. "Algumas lideranças do Movimento Negro, como Vilma Santos de Oliveira [dona Vilma], além de reivindicar a adoção de vagas no vestibular da UEL, manifestavam preocupação diante da necessidade de garantir a permanência dos estudantes negros" (Silva 2008b:5).

A abordagem de agremiações como a AROL e de atores como dona Vilma e Manoel Cypriano permite novas possibilidades de percepção do negro em Londrina além daquelas presentes na história oficial, nos museus, monumentos e espaços públicos.

Assim, com o estudo da missa afro é possível destacar a continuidade desses processos de enfrentamentos. Nesses ritual católico constata-se o desdobramento dessas ações de combate ao racismo e à discriminação do negro no Brasil e, sobretudo, em Londrina, local onde vivem os atores pesquisados.

\section{A missa afro}

Na Arquidiocese de Londrina a missa afro é realizada apenas na paróquia Nossa Senhora dos Migrantes, Cambé, e na paróquia Santo Antônio, região sul de Londrina. Embora exista na região uma população negra significativa, a pastoral afro está presente em poucas paróquias. Assim, percebe-se um esforço contínuo dessas lideranças no sentido de instituir a missa afro em outras paróquias da Arquidiocese. Há, assim, certo sentimento de frustração por esses agentes ao perceber que a aceitação dessa pastoral é restrita. Em seus discursos, uma das críticas é sobre os poucos padres negros que não aderem ao movimento: "mesmo padres negros não se assumem", lamentou o assessor da pastoral afro-brasileira.

Por outro lado, juntamente com os padres organizadores da missa afro, que são negros, há um padre branco, precursor da missa afro na Arquidiocese. Além desse sacerdote, há ainda um número considerável de leigos brancos presentes nessas missas.

Dados do IBGE de 2010 apontam que em Londrina 26,07\% da população é composta por afrodescendentes. No entanto, observando 
a questão territorial, a população negra possui maior concentração nas periferias da cidade, enquanto nas áreas centrais e periféricas/ nobres $^{8}$ a população de cor branca é maior. Assim como em outras cidades brasileiras, "a população negra tem, historicamente, ocupado lugares discriminados e estigmatizados" (Silva 2008b:2). De acordo com a cientista social, "a distribuição da população negra na cidade apresenta uma maior presença em territórios considerados discriminados, pobres e marginalizados ou de menor prestígio" (Silva 2008b:3). Nesse sentido, as paróquias onde há a celebração da missa afro está diretamente associado a espaços onde a presença do negro é maior. No entanto, nem toda paróquia localizada em regiões periféricas pobres realizam essa missa.

$\mathrm{Na}$ paróquia dos Migrantes a missa afro é realizada desde 1988, ano em que a CNBB escolheu o tema 'A fraternidade e o negro'. O coordenador da pastoral afro nessa paróquia é um líder muito atuante e responsável por sua realização. $\mathrm{O}$ pároco também demonstra apoio à realização dessa missa, não apenas oferecendo o espaço físico, mas também participando ativamente em sua celebração. Nessas ocasiões, é um dos que utilizam roupas típicas da África. Enquanto sacerdote, sua túnica se distingue das demais missas, além de usar o kufi ${ }^{9}$.

Uma das missas em que participei, um dos primeiros aspectos percebidos foi a disposição dos bancos. Nas missas semanais, eles ficam tradicionalmente enfileirados, como nas demais paróquias. Já na missa afro eles são colocados em forma circular, de maneira que quem se assenta em um lado do templo pode visualizar aqueles que se encontram na outra extremidade.

Nesse dia, os bancos ficaram completamente tomados por fieis, maior parte da própria paróquia dos Migrantes. Havia também pessoas de outros lugares interessadas nesse evento. Pessoas de todas as idades e ambos os sexos estavam presentes. Sobre a cor da pele dos participantes havia certa diversidade, com pessoas brancas, pardas e pretas $^{10}$. Ao contrário da expectativa, os participantes não eram estritamente negros. 
Enquanto os fieis usavam roupas do cotidiano, integrantes do clero e demais lideranças da pastoral afro trajavam roupas e adereços que buscavam lembrar a cultura africana, normalmente com cores diversificadas. Mesmo com alguns limites em alcançar tal objetivo, tal tentativa em aproximar-se do estilo africano se opõe ao formalismo da Igreja Católica que utiliza cores específicas segundo o calendário litúrgico $^{11}$. Assim, ao usar roupas coloridas, a simbologia associada a uma cor específica do calendário oficial católico é substituída por outra, multifacetada, alegre, sem vínculo com a tradição oficial, demonstrando assim, certa autonomia.

As músicas e danças também contribuíram para criar um ambiente afro à missa. Além dos instrumentos comumente usados no cotidiano da paróquia, como violão e teclado, havia também instrumentos de percussão, como tambor e atabaque, que ajudavam a marcar o ritmo. Além disso, a alegria dos músicos e seu balanço ao ritmo de cada canção também diferenciavam das missas oficiais, onde há uma forma bem comedida, sem muita expressividade, passando até mesmo despercebidos em muitas ocasiões. O seu destaque na missa afro foi algo evidente, bem como a maneira como participaram dela.

As letras possuíam forte caráter político, problematizando a questão racial:

Eu vou tocar minha viola, eu sou um negro cantador

O negro canta deita e rola, lá na senzala do Senhor.

Dança aí negro nagô, dança aí negro nagô

Dança aî negro nagô, dança aî negro nagô.

Tem que acabar com esta história de negro ser inferior

O negro é gente e quer escola, quer dançar samba e ser doutor.

O negro mora em palafita, não é culpa dele não senhor

A culpa é da abolição que veio e não o liberou.

Vou botar fogo no engenho aonde o negro apanhou

$\mathrm{O}$ negro é gente como o outro, quer ter carinho e ter amor ${ }^{12}$. 
A oração do pai nosso, uma das mais conhecidas e utilizadas no cristianismo, ganhou uma versão diferente em uma das músicas tocadas durante a missa afro:

Pai nosso, dos pobres marginalizados

Pai nosso, dos mártires, dos torturados.

Teu nome é santificado naqueles que morrem defendendo a vida,

Teu nome é glorificado, quando a justiça é nossa medida

Teu reino é de liberdade, de fraternidade, paz e comunhão.

Maldita toda a violência que devora a vida pela repressão.

Ô, o, o, o. Ô, o, o, o.

Queremos fazer Tua vontade, és o verdadeiro Deus libertador

Não vamos seguir as doutrinas corrompidas pelo poder opressor.

Pedimos-te o pão da vida, o pão da segurança, o pão das multidões.

O pão que traz humanidade, que constrói o homem em vez de canhões.

Ô, o, o, o. Ô, o, o, o.

Perdoa-nos quando por medo ficamos calados diante da morte,

Perdoa e destrói os reinos em que a corrupção é mais forte.

Protege-nos da crueldade, do esquadrão da morte, dos prevalecidos

Pai nosso, revolucionário, parceiro dos pobres, Deus dos oprimidos.

Pai nosso, revolucionário, parceiro dos pobres, Deus dos oprimidos.

Ô, o, o, o. Ô, o, o, o.

Pai nosso, dos pobres marginalizados

Pai nosso, dos mártires, dos torturados ${ }^{13}$.

Nesse canto, a questão racial não é evidenciada exclusivamente. A crítica recai sobre pessoas excluídas e marginalizadas socialmente. Os mártires, ou seja, os que lutam pela vida e pela justiça, e que de alguma forma são punidos por isso, recebem atenção especial. $\mathrm{O}$ negro, no entanto, pode ser percebido como parte desses grupos marginalizados e excluídos historicamente no Brasil. Os mártires do passado que lutaram pela liberdade, por exemplo, se tornam referências para os atores sociais do presente, devendo estes prosseguir na mesma causa. 
Isso se ratifica na homilia feita por um padre durante a missa afro: "Nós precisamos romper com esse império de morte, esse império de preconceito, trezentos anos de escravidão, trezentos anos de sofrimento dos nossos negros. Já aconteceu a abolição de cor, mas nós precisamos da abolição do preconceito. Nós precisamos da abolição do racismo" 14 , reivindicou o jovem sacerdote.

A figura do leigo ganhou importância nessa missa. Se na homilia, ainda existe um viés hierárquico, onde o clero possui seu espaço assegurado, o leigo ocupou um espaço significativo ao poder contribuir em parte da missa. A música é um exemplo disso: ela é espaço em que ecoa a voz do leigo atuante na pastoral afro. Cuidadosamente escolhidas, as letras reafirmaram a homilia do clero e, em alguns casos, de forma muito peculiar, como percebido na música Pai nosso dos mártires.

Em dois sentidos as músicas conseguiram estabelecer um sentido de protesto na missa: a) por meio das letras contestatórias em relação ao pobre e excluído em geral, e ao negro em particular e b) no ritmo que remete às origens africanas daqueles que aqui chegaram para trabalhar sob o sistema da escravidão. As músicas tradicionais, que muitas vezes utilizam palavras em latim, em um ritmo moderado, influência da missa romana, são trocadas por um ritmo intenso, que leva todos a dançar, ainda que timidamente. Uma mulher presente pela primeira vez na missa afro, ao final disse: "gostei! Bem mais animada que nas demais [missas]".

Em momentos específicos, um grupo de participantes entrava e saia, ao som de músicas em ritmo afro, dançando e cantando, ora com cestos de alimentos, contendo frutas, bolos e doces, ora com a Bíblia ou com a imagem de algum santo. Nesse sentido as mulheres se destacavam, sendo a maioria. Alguns poucos homens também ajudavam nesses momentos.

Em outro momento foi realizada uma encenação: grupos de três a quatro pessoas negras, a uma distância média entre eles, ficavam abraçados. Enquanto isso, algumas pessoas brancas e algumas carre- 
gando pequenos aparelhos de rádio circulavam entre os grupos de negros sem notar sua presença. Com isso denunciava a invisibilidade do negro pelos brancos e por setores da mídia. Durante a homilia, o sacerdote denunciou o papel subalterno que o negro teve no Brasil, desde a escravidão até os dias atuais.

A presença da mulher é significativa na pastoral afro da paróquia dos Migrantes. Exceto o seu coordenador, os demais participantes dessa pastoral são todas mulheres e negras. Dessas, a maioria já são senhoras e avós, como pude perceber em suas conversas, quando era comum o relato de casos familiares.

A participação de mulheres em maior número do que a de homens em grupos de CEBs em Garanhuns - CE, recebeu atenção na pesquisa de Marjo de Theije (2002). De acordo com a antropóloga holandesa, a explicação para isso foi dada de forma unânime pelos homens daquela localidade, ao afirmar que "religião é coisa de mulher". Isso reflete os ideais de gênero presentes na sociedade brasileira. Constatou a autora que a participação das mulheres não era apenas maior que a dos homens, mas havia uma multiplicidade de atuação dessas mulheres, que transcendia às CEBs. Atuavam em diversas pastorais e até mesmo em grupos de oração carismáticos.

Essa distinção de gênero era perceptível inclusive nas crianças. Relata a autora o caso de um menino de sete anos explicando o fato de não ia à missa por ser 'coisa de mulher', reforçando "a ideia de que o envolvimento com a religião não se encaixa com a imagem de masculinidade da sociedade brasileira. A imagem da feminilidade, por sua vez, está relacionada com atitudes e valores que podem ser associados às atividades religiosas" (Theije 2002:218).

Carol Drogus (1990) também identificou em alguns grupos de CEBs em São Paulo o mesmo fato. Constatou a autora que embora o discurso da Teologia da Libertação tenha conseguido mobilizar um número significativo de mulheres em torno das CEBs, há, no entanto, a dificuldade em confrontar a crença de que o papel central da mulher está no âmbito familiar. 
No Brasil, bem como de forma geral na América Latina, a divisão entre masculino e feminino é reforçado por símbolos religiosos, como o marianismo, em que a veneração à Virgem Maria e a percepção de sua divindade, superioridade moral e força espiritual (Drogus 1990) é associado à mulher de forma geral.

Pode-se perceber, portanto, nas mulheres que participam da pastoral afro na Migrantes, algumas divergências. Ao mesmo tempo em que participam de uma pastoral que traz um elemento político em seus rituais, reproduzem as distinções de gênero das quais elas mesmas estão submetidas. É comum, portanto, ouvir nas reuniões a ideia da mulher na esfera privada do lar, ao falar dos filhos e netos ou mesmo a demonstração de certas preocupações com o trabalho doméstico.

Sobre a questão racial, embora exista certa orientação sobre a realidade do negro no Brasil, isso parece não ter entendimento entre o próprio grupo. Durante uma reunião da pastoral afro, ao surgir o assunto sobre a cor da pele e o cabelo crespo, uma senhora lamentou: "mas a gente nasceu assim, né, fazer o quê?". Assim, a análise que Carol Drogus (1990) faz das CEBs em São Paulo também pode ser percebida na paróquia dos Migrantes: a Teologia da Libertação, por meio da pastoral afro, consegue atrair para seus quadros fieis, sendo a maioria mulheres e negras. No entanto, há certa dificuldade em avançar nas propostas de transformação da realidade social, primeira do negro, que é o objetivo primeiro dessa pastoral, e posteriormente da mulher, cuja presença é majoritária nesse grupo católico.

Em uma reunião dessa pastoral não havia nenhum jovem. Já na missa afro houve a presença de alguns na liturgia. Nesse caso, o vínculo principal deles era com a Pastoral da Juventude, que via nesses momentos um espaço de luta comum, demonstrando certa identificação com o tema, bem como o desenvolvimento de uma religiosidade a partir das contribuições da Teologia da Libertação, entrelaçando-se nessas ocasiões.

Na missa afro também houve ajuda de fieis de outras pastorais e sem a mesma afinidade ideológica. É o caso de uma católica, negra, 
que trabalha na pastoral da comunicação, além de ser ministra da eucaristia na Migrantes. Muito alegre e gentil, estava na entrada do templo, auxiliando naquilo que podia. Não era sua primeira participação na missa afro. Em edições anteriores, também esteve presente ajudando na organização do evento. Segundo ela, ajuda sempre que é preciso, assim como os demais eventos que ocorrem na paróquia, organizados por outros grupos, sem possuir vínculo com a Teologia da Libertação necessariamente.

Em conversa informal se demonstrou interessada por política. Embora o interesse fosse meu em perceber a relação entre religião e política, partiu dela o assunto sobre política, especialmente o aspecto partidário. Revelou que se candidataria nas eleições de 2016 ao cargo de vereadora pelo PSDB, na cidade de Cambé. Embora fosse filiada a esse partido desde 2009, revelou identificar-se, na verdade, com o PMDB. Por razões particulares, acabou filiando-se ao PSDB.

$\mathrm{Na}$ época da pesquisa, dois fatos podem ser destacados em relação ao PMDB: o primeiro ocorreu no final de março de 2016, com o desligamento oficial da aliança com o PT. No encontro nacional do partido liderado pelo senador Romero Jucá (PMDB-RR), Eduardo Cunha (PMDB-RJ), presidente da Câmara dos Deputados na época, recebeu forte visibilidade, além dos gritos da plateia que dizia 'Temer presidente!', embora ele não estivesse presente nessa reunião do partido $^{15}$. Assim, diante do processo pelo qual o PT teve sua imagem fragilizada ${ }^{16}$, o fim da aliança com o PMDB atraiu a atenção de parcela significativa da população que estava descontente.

Um segundo elemento também pode ser acrescentado: havia passado aproximadamente um mês a aprovação de abertura do processo de impeachment da presidente Dilma Rousseff na Câmara dos Deputados, presidida por Eduardo Cunha. Os anseios pelo afastamento da presidente, por um número cada vez maior de pessoas, encontrou nesse parlamentar certa esperança no processo de mudança na política nacional. Assim, sua identificação ao PMDB parece ter sido desenvolvida a partir desse momento de efervescência política no país, 
onde esse partido se demonstrava capaz de enfrentar e conduzir as mudanças necessárias.

Tal posicionamento político, entre a filiação ao PSDB e identificação com o PMDB, embora uma fiel negra e participante das missas afro na paróquia dos Migrantes, demonstra que a compreensão dos objetivos propostos pela pastoral afro possui uma gama de interpretações por parte dos fieis que dela participam. O exemplo dessa mulher torna-se emblemático demonstrando que, ao fazer a opção política por esses dois partidos, parece não perceber que ambos não possuem participação efetiva nas principais conquistas alcançadas a favor do negro, como o Estatuto da Igualdade Racial ${ }^{17}$, a lei de cotas nas universidades ${ }^{18}$ e o Dia da Consciência Negra ${ }^{19}$. Nesse mesmo sentido, foi criada sob o governo Lula a Universidade da Integração Internacional da Lusofonia Afro-Brasileira (UNILAB), sob a lei 12.289/2010²0. Esses avanços sociais em relação à questão étnico-racial podem ser percebidos como resultado dos esforços desenvolvidos por meio do movimento negro, ocorridos nos governos Lula e Dilma.

Por outro lado, havia a presença de um vereador de Cambé filiado ao PT, mesmo não sendo negro, de uma outra paróquia da cidade. Seu vínculo à Teologia da Libertação se evidencia por possuir outras participações dentro do catolicismo, como é o caso da romaria da terra. Em sua página em uma rede social, fez algumas críticas ao PMDB na época da votação do impeachment de Dilma Rousseff, na Câmara dos Deputados, em Brasília.

Dessa maneira, a questão partidária na missa afro demonstra algumas contradições entre os participantes, indicando certas dificuldades enfrentadas pelo clero no processo de desenvolvimento de identidades progressistas entre os fieis. Necessita, assim, certa complementaridade de outras instituições ou pastorais. No caso desse vereador, seu vínculo ao PT pode ser visto como esse elemento formador para além da missa afro. Alguns jovens da Pastoral da Juventude, com sua própria dinâmica religiosa, também proporciona a construção de uma visão de mundo progressista. Já os fieis que não possuem outros vín- 
culos nos quadros da Teologia da Libertação, demonstram possuir certa dificuldade em assimilar as propostas da missa afro que se torna, assim, mais uma programação paroquial para esses fieis.

Se a cor da pele dos fieis era, em geral, diversificada, a do clero, bem como dos organizadores da pastoral afro da paróquia era predominantemente preta. O engajamento mais efetivo nessa pastoral está, portanto, associada à cor da pele. As experiências de preconceito e racismo que acomete o negro no Brasil contribuem, dessa forma, para a construção de um espaço no âmbito eclesiástico onde essas violências possam ser refletidas e até mesmo enfrentadas. Um sacerdote, no início de sua homilia declarou: "O nosso Brasil é branco, machista e cristão, infelizmente. Nós precisamos quebrar essa imagem”21. Dessa maneira, a compreensão do ser negro é percebida de forma distinta entre o clero e o leigo. No caso do clero, a negritude, enquanto identidade, remete a um espaço de luta dentro dos quadros da instituição católica, nesse caso, a pastoral afro. Já para parte dos leigos, o fato de ser negro não o leva necessariamente à participação nessa pastoral, podendo fazer outras escolhas, até mesmo simultâneas. Participar da missa afro, não é diferente de participar da pastoral da comunicação, da pastoral do dízimo ou ministério da eucaristia.

Percebe-se também que a participação do fiel negro é limitada na missa afro da paróquia dos Migrantes ${ }^{22}$. O mesmo pode ser pensado no clero arquidiocesano, onde há sacerdotes negros que não participam da missa afro, nem apoiam o desenvolvimento de uma pastoral afro em suas paróquias.

A missa afro, portanto, busca problematizar os preconceitos e desigualdades raciais no país sofridos pela população negra. Conscientizar o negro de sua história e situação de subserviência demonstra ser sua principal missão: "Poucos os padres negros e alguns que tem ainda não assumem a sua cor. Então nós precisamos dar visibilidade para o nosso negro. Como? A partir de nós mesmos. Usando a igreja para discutirmos essa questão do racismo, ascensão, inclusão, quebrando preconceito de muitos cristãos" ${ }^{\prime 2}$. 
O pároco da Migrantes também vê na missa afro um dos principais instrumentos de contestação política no contexto local:

"a pastoral afro vai trazer isso, elementos da cultura africana na liturgia, celebração, e ao mesmo tempo participar das políticas públicas de defesa e promoção dos direitos da pessoa, do negro, da pessoa como um todo, a gente sabe inclusive que o índice de mortalidade, por exemplo, entre os jovens, as próprias estatísticas mostram isso, nossos jovens e, jovens negros, morrem muito mais que jovens brancos, isso não por razões inúteis, mas por razões muito claras, né?"24

Frente ao movimento negro que é mais amplo e que abarca diversos setores sociais, estabelecendo a crítica em relação ao preconceito, discriminação e violência, a missa afro desenvolve discussões semelhantes, porém, restrita ao âmbito da Igreja Católica. Por um lado, amplia o alcance do movimento negro no Brasil; por outro, no entanto, restringe ao âmbito da religião católica, negando outras religiões e segmentos da sociedade, que também estabelecem a mesma crítica sóciopolítica.

Gabriel dos Santos Filho percebe na pastoral afro-brasileira, por meio de suas pautas de reivindicações, similaridade com o movimento negro: "É com esta amplitude de visão que se pode considerar a Pastoral Afro como integrante do movimento negro, dado ser reconhecido que onde há negro militando, há movimento negro" (Santos Filho 2012:70). Para o autor, a construção de identidades por meio de aspectos comuns é capaz de aglutinar os movimentos negros em torno dessa agenda.

Apesar de ser um movimento negro, como considera Santos Filho (2012) dentro do catolicismo, a realização dessa missa pela pastoral afro se limita a um viés paroquial, em última instância, estruturado pela instituição religiosa católica que a abriga. A presença dessa pastoral na Arquidiocese de Londrina pode ser vista nesse sentido: um espaço concedido a partir de determinadas condições. $\mathrm{O}$ próprio arcebispo, nesse caso, recebe uma imagem positiva por parte de algumas lideranças, por permitir a existência e desenvolvimento de 
práticas religiosas em torno do negro: "o arcebispo dá total apoio", relatou um padre.

Em uma publicação no jornal Folha de Londrina ${ }^{25}$, no dia 21 de novembro de 2015, o arcebispo de Londrina abordou a festa de Cristo Rei. A data ocorreu um dia após a comemoração do dia da consciência negra. No artigo o arcebispo exalta a importância e centralidade de Jesus no catolicismo, afinal, ele é "o rei dos pecadores, dos pobres, dos últimos, dos pequenos, dos que procuram a verdade" ${ }^{26}$. No final do artigo, após falar da criação, da manjedoura, da cruz e do sacrifício de Jesus, o arcebispo declarou: "Adorar Cristo Rei é antes de tudo servi-lo nos excluídos, empobrecidos, marginalizados. Longe de nós o racismo, a tortura, a fome, a prostituição que denigrem a dignidade da pessoa, templo do Espírito Santo"27. O racismo, além de ter sido mencionado apenas uma vez no fim do texto, foi colocado junto a outras questões, como tortura, fome e prostituição. Sua inserção pode ter sido em relação ao dia da consciência negra, no entanto, sem mencionar a data ou demonstrar qualquer sinal de apoio. Além disso, o termo 'denigrem', utilizado pelo arcebispo, expressa o ato de enegrecer, manchar ou infamar, segundo o dicionário Aurélio ${ }^{28}$. Se por um lado defende o fim do racismo, por outro, ao utilizar o termo 'denegrir', pode expressar segundo a interpretação que ser negro é algo ruim, termo pejorativo ou uma desqualificação.

No artigo, o arcebispo demonstrou a exaltação da figura de Jesus e sua importância para a religião católica, enquanto o negro recebeu uma atenção mais discreta. Dessa forma, a concepção de alguns agentes negros que o avaliam positivamente por apoiar a pastoral afro, $\mathrm{o}$ artigo publicado na data seguinte ao dia da consciência negra demonstra o contrário. $\mathrm{O}$ apoio que percebem no bispo se caracteriza mais pela permissão em desenvolver trabalhos sob o viés da questão racial do que por uma atuação mais efetiva junto à pastoral afro.

Apesar da pouca aceitação pela maioria do clero da Arquidiocese e mesmo por parte dos fieis da paróquia dos Migrantes, a missa afro vem aos poucos conquistando a simpatia de católicos ${ }^{29}$. No início 
provocou muitas críticas da comunidade, especialmente por desenvolver ritos parecidos aos das religiões afro-brasileiras, marcadas por inúmeros preconceitos no país. Assim, percebe-se que, se o objetivo é refletir sobre o problema do racismo e preconceito que recaem sobre o negro, parcialmente isso tem sido alcançado, por meio da realização dessas missas. $\mathrm{O}$ número de presentes nessa missa indica sua crescente aceitação na paróquia.

\section{Considerações finais}

Há na missa afro considerável esforço em desenvolver na paróquia Nossa Senhora dos Migrantes um espaço de reflexão sobre o negro no país e, assim, contribuir na superação do preconceito e do racismo, ainda presentes na atualidade.

Há cerca de cinco padres envolvidos diretamente na organização desse rito católico, sendo a maioria de negros, o que demonstra um interesse pessoal, a partir de suas possíveis experiências sobre ser negro no Brasil. Esses padres que participam da missa afro, entre eles um branco, estão todos inseridos em paróquias periféricas da Arquidiocese de Londrina, onde existe maior concentração da população negra e, consequentemente, é evidenciado as desigualdades e injustiças caracterizadas pela raça/etnia. Não há participação de membros do clero pertencentes à paróquias centrais ou de bairros 'nobres'.

Embora seja um rito que receba a permissão do arcebispo, é um evento pontual, sem muita evidência na Arquidiocese. Os atores envolvidos, seja do clero ou do laicato, assumem a responsabilidade da organização e condução do evento em média duas vezes por ano, sendo sempre os mesmos a presidir a missa. Por não ser um evento comum, atrai fieis de várias regiões da Arquidiocese que se identificam com a temática.

Embora a missa afro seja vista como extensão no movimento negro no catolicismo (Santos Filho 2012) não foi possível perceber muita aproximação entre ambos. Em certa ocasião, havia apenas uma 
mulher integrante do movimento negro participando do evento. Percebe-se assim que, embora as pautas sejam semelhantes, há certo distanciamento entre ambos.

A abordagem sobre o negro ocorre especialmente a partir do viés social e político, enquanto o elemento cultural é tratado parcialmente. Não houve aproximação das religiões de matrizes afro, como o candomblé e a umbanda, cujos adeptos também são discriminados. Embora as roupas e danças presentes na missa afro lembrem os rituais dessas religiões, a condução e participação se restringiu à religião católica, limitando assim, o desenvolvimento de ações de combate ao preconceito e discriminação relacionados ao negro.

Há uma variedade de interpretações que os fieis fazem da missa afro. Há pessoas inseridas em partidos políticos de esquerda, de pastorais progressistas como a PJ, que fazem desse espaço um lugar de luta pela causa do negro, como também fieis pertencentes a pastorais sem cunho político e até mesmo vinculadas a partidos conservadores. Nesse último caso, a missa afro é apenas mais um evento entre vários no interior do catolicismo.

Por estar vinculada à estrutura da Igreja Católica, a missa afro enfrenta certas limitações no desenvolvimento de ações de combate ao racismo. Mesmo assim, os agentes estudados neste artigo buscam formas de conciliação entre a estrutura católica e seus interesses sociopolíticos.

\section{Notas}

1 A coletânea foi produzida no âmbito do Laboratório de Cultura e Estudos Afro -Brasileiros - LEAFRO - da Universidade Estadual de Londrina.

2 Nelson Dacio Tomazi (2000) em sua pesquisa sobre a região norte do Paraná destaca que a presença de sociedades tribais nessas terras possui cerca de 7.000 anos. 3 Há em Londrina monumentos em homenagem a alguns grupos étnicos que contribuíram para a construção da cidade. Destaco alguns: 1) a praça da bandeira, da década de 1940, possui um formato que lembra a bandeira da Grã-Bretanha; 2) 
a praça Tomi Nakagawa na região central, inaugurada em 2008, retrata o centenário da imigração japonesa; 3) a passarela inspirada na torre Big Ben construída na entrada da cidade pela BR-369, na região oeste, e inaugurada em 2014; 4) o shopping Boulevard, construído recentemente na região central. Sua decoração remete aos ingleses.

4 'Histórias e fantasmagorias' é o subtítulo da obra de Tomazi (2000), denominada 'Norte do Paraná'. O autor refere à História o modo como os homens produzem a sua existência, seu modo de vida, enquanto fantasmagoria seria a possibilidade da manipulação das lentes para alterar a imagem projetada, ou seja, a manipulação do real.

5 Idalto José de Almeida elaborou este trabalho a partir de seu interesse e experiência no movimento negro em Londrina por mais de duas décadas. Contem relatos e depoimentos de lideranças negras que participaram ativamente da história da cidade, além de experiências das quais o próprio autor participou. É, portanto, uma fonte secundária sobre a discussão referente ao negro em Londrina, sendo, portanto, relevante para o propósito deste artigo.

6 Arthur Thomas nasceu na Escócia e chegou ao Brasil em 1924 com o objetivo de organizar uma empresa de capital inglês, que venho a ser a CTNP, sendo o seu diretor. Assim, é considerado um dos fundadores de Londrina. Seu nome está em um parque e em uma avenida da cidade.

7 O processo de implantação de cotas na UEL iniciou em 2002 por meio da iniciativa de lideranças do movimento negro em Londrina. A partir daí foram realizados diversos debates, além de uma audiência pública. Foi aprovada no dia 23 de julho de 2004, em votação no Conselho Universitário da UEL.

8 Com a construção de vários condomínios horizontais de luxo em áreas periféricas de Londrina nos últimos anos, a questão centro/periferia como sinônimo de divisão de classes não pode ser utilizada atualmente. Há um deslocamento de famílias que viviam em bairros nobres mais centralizados para esses condomínios afastados, resultando na presença cada vez maior de famílias de classe média/alta nessas áreas 'periféricas'. Se no passado o sentido de periferia se referia a espaços onde era abrigada a classe trabalhadora, hoje há cada vez mais a formação de uma periferia abastada. Esse fenômeno também tem ocorrido em outras cidades do Brasil. Teresa P. Caldeira analisa na cidade de São Paulo a construção dos 'enclaves fortificados', como os shoppings e condomínios. Para a autora, os enclaves são "propriedade privada para uso coletivo e enfatizam o valor do que é privado e restrito ao mesmo tempo que desvalorizam o que é público e aberto na cidade. São fisicamente demarcados e isolados por muros, grades, espaços vazios e detalhes arquitetônicos. São voltados para o interior e não em direção à rua, cuja vida pública rejeitam explicitamente. São controlados por guardas armados e sistemas de segurança, que impõem regras de inclusão e exclusão" (2000:258). Para aprofundar o assunto, ver: Teresa P. Caldeira 2000 do Rio. Cidade de muros: crimes, segregação e cidadania em São Paulo. São Paulo: Editora 34/Edusp,.

9 O kufi é um adereço utilizado na cabeça. Ele não possui abas e normalmente possui várias cores. É símbolo de sabedoria na África, sendo utilizado por homens adultos. 
O IBGE adota como critério de classificação as seguintes categorias: branco, preto, pardo, amarelo e indígena. A população negra é composta por pretos e pardos. A observação dos fieis presentes na missa afro, portanto, foi feita por meio da impressão fenotípica, baseada em categorias tradicionais, como observa Pierre Sanchis (2001).

11 Há quatro cores principais que compõe o ano litúrgico: branco, vermelho, verde e roxo. $\mathrm{O}$ branco é utilizado na páscoa, natal etc. $\mathrm{O}$ vermelho na sexta-feira da paixão. $\mathrm{O}$ verde nos domingos do tempo comum e o roxo no advento e quaresma.

12 Música negro nagô. Autoria: PJ e Raiz.

13 Música 'Pai nosso dos mártires'. Autoria: Zé Vicente.

14 Gravação 15112015 - folha 1.

15 E o PMDB abandonou o PT. Carta Capital. 29 mar. 2016. www.cartacapital. com.br. Acesso em: 09 ago. 2016.

16 O processo de fragilização do PT contou com apoio da grande mídia; de partidos políticos da oposição, como o PSDB e o DEM; e do judiciário, por meio da operação Lava Jato que concentrou os esforços nas investigações desse mesmo partido. Deysi Cioccari (2016) analisou na editoria Poder, do jornal Folha de São Paulo, os últimos meses do processo de impeachment de Dilma Rousseff, de 15 de abril a 31 de agosto de 2016, quando o Senado aprovou definitivamente o seu afastamento. Para a cientista social, as informações chegam a todo tempo ao público não apenas pelos jornais e TV, mas também pelos novos equipamentos eletrônicos como tablets, smartphones e computadores. Assim, "a mídia possui a capacidade de formular as preocupações públicas” (Cioccari 2016:173). A definição da agenda política pelos meios de comunicação não afeta apenas o cidadão comum, que percebe a pauta mais importante do momento, mas também lideranças políticas que buscam responder a esses anseios. Conclui a autora que o editorial nos últimos meses do governo Dilma deixou claro ao público que seu impeachment era algo iminente. Somando-se a isso, tratou o 'possível governo Temer' como um governo já estabelecido, antes mesmo da votação final no Senado.

17 O ex-presidente Lula sancionou em julho de 2010 a lei 12.288: o Estatuto da Igualdade Racial. Já no Art. 1º, afirma: "Esta Lei institui o Estatuto da Igualdade Racial, destinado a garantir à população negra a efetivação da igualdade de oportunidades, a defesa dos direitos étnicos individuais, coletivos e difusos e o combate à discriminação e às demais formas de intolerância étnica". Para ser lida na íntegra, consultar: www.planalto.gov.br/ccivil_03/_ato2007-2010/2010/lei/112288.htm; acesso em: 21/11/2016.

18 A lei 12.711/2012 também conhecida como Lei de Cotas, foi sancionada pela presidente Dilma Rousseff em agosto de 2012. A lei prevê a oferta de $50 \%$ das vagas de universidades e institutos federais para alunos que cursaram o ensino médio integralmente em escola pública e de baixa renda. Essas vagas são proporcionais ao número de pretos, pardos e indígenas referentes a cada estado brasileiro. Há também a lei 12.990/2014, em que $20 \%$ das vagas em concursos públicos federais são destinadas a candidatos negros. A lei 21.711 pode ser lida no endereço: www.planalto. gov.br/ccivil_03/_ato2011-2014/2012/Lei/L12711.htm. Já a lei 12.990 pode ser 
encontrada no endereço: www.planalto.gov.br/ccivil_03/_Ato2011-2014/2014/ Lei/L12990.htm; acesso em: 21/11/2016.

19 Além da instituição do Dia da Consciência Negra, a lei 10.639/2003 inclui na LDB 9.394 de 1996 a obrigatoriedade da temática História e Cultura Afro-Brasileira no currículo escolar.

20 A UNILAB possui atualmente dois campus: Redenção (Ceará) e São Francisco do Conde (Bahia). Tem como objetivo a integração entre docentes e discentes do Brasil e África lusófona. A lei 12.289/2010 pode ser encontrada na íntegra no endereço: www.planalto.gov.br/ccivil_03/_Ato2007-2010/2010/Lei/L12289.htm; acesso em: 21/11/2016.

21 Gravação missa afro - 15112015, folha 1.

22 "A pastoral afro [...] é uma pastoral que sofre né, ela tem poucos membros porque ela exige um grau de consciência muito forte, a sua própria identidade dentro da comunidade, ou seja, muitos negros não participam da pastoral afro por razões obvias que nós sabemos, eles próprios sentem que se entrar na pastoral afro vou me tornar visível e é melhor ser invisível porque sendo invisível não sou criticado, porque nós temos uma tradição de racismo muito mascarada na cultura brasileira". Entrevista, pároco N. Sra. dos Migrantes, 2705215 - folha 2.

23 Gravação missa afro - 15112015, folha 1.

24 Entrevista, pároco N. Sra. dos Migrantes, 27052015 - folha 2.

25 A Folha de Londrina é o principal jornal da cidade. Na coluna Espaço Aberto embora seja destinado ao público em geral, no período da pesquisa foram publicados diversos textos de dom Orlando, especialmente nos finais de semana.

26 Os tronos de Cristo Rei. Folha de Londrina. Opinião, p. 2, 21 nov. 2015.

27 Os tronos de Cristo Rei. Folha de Londrina. Opinião, p. 2, 21 nov. 2015.

28 Rio de Janeiro: Nova Fronteira, 1985.

29 Isso é constado no início da homilia de um sacerdote: "A missa afro na Nossa Senhora dos Migrantes já virou uma tradição, isso é bom porque eleva nossa autoestima, valoriza nossa etnia, a nossa cultura, a nossa cor, o nosso jeito de ser". Grifos nossos. Gravação 15112015 - folha 1.

\section{Referências}

ALMEIDA, Ana Maria. 1997. A Morada do Vale: sociabilidade e representações; um estudo sobre as famílias do Heimtal. Londrina: EDUEL.

. 2009. Memória e identidade da população afro-brasileira em Londrina-PR. TrabaIho apresentado no XIV Congresso Brasileiro de Sociologia. Rio de Janeiro - RJ.

ALMEIDA, Idalto José de. 2004. Presença negra em Londrina: história da caminhada de um povo. Londrina: Atrito Art. 
BOURDIEU, Pierre. 1989. O poder simbólico. Lisboa: DIFEL.

CIOCCARI, Deysi. 2016. "A queda: os últimos meses de Dilma Rousseff pelas páginas do jornal Folha de S. Paulo”. Revista Alterjor, 14(02):168-187.

DROGUS, Carol Ann. 1990. "Reconstructing the Feminine: Women in São Paulo's CEBs”. Archives de Sciences Sociales des Religiones, 71:63-74.

HALBWACHS, Maurice. 2004. A memória coletiva. São Paulo: Centauro.

LANZA, Fabio [et al]. 2013. Yá Mukumby: a vida de Vilma Santos de Oliveira. Londrina: UEL.

LE GOFF, Jacques. 2003. História e memória. Campinas: Editora da Unicamp.

MUNANGA, Kabengele. 2006. Rediscutindo a mestiçagem no Brasil: identidade nacional versus identidade negra. Belo Horizonte: Autêntica.

ORTNER, Sherry. 2011. "Teoria na antropologia desde os anos 60". Mana 17(2):419-466.

PADIS, Pedro Calil. 1981. Formação de uma economia periférica: o caso do Paraná. São Paulo/ Curitiba: Hucitec/ Secretaria da Cultura e do Esporte do Governo do Estado do Paraná.

POLLAK, Michel. 1989. "Memória, esquecimento e silêncio". Estudos Históricos, 3(3):3-15.

SANCHIS, Pierre. 2001. "Culto e cultura, liturgia e afirmação étnica: a vivência da 'missa afro' no Brasil". In SANCHIS, Pierre (ed.): Fieis e cidadãos: percursos de sincretismo no Brasil, pp. 147-180. Rio de Janeiro: EdUERJ.

SANTOS FILHO, Gabriel dos. 2012. O catolicismo brasileiro e a construção de identidades negras na contemporaneidade: um olhar socioantropológico sobre a Pastoral Afro-Brasileira. Salvador: EDUFBA.

SILVA, Maria Nilza da. 2008a. O lugar da população negra numa cidade brasileira: Londrina espaço de segregação e resistência. Trabalho apresentado no VI Congresso Português de Sociologia, Lisboa, Portugal.

. 2008b. "O negro em Londrina: da presença pioneira negada à fragilidade das ações afirmativas na UEL”. Revista Espaço Acadêmico, 82:1-10.

THEIJE, Marjo de. 2002. Tudo o que é de Deus é bom: uma antropologia do catolicismo liberacionista em Garanhuns, Brasil. Recife: Massangana.

TOMAZI, Nelson Dacio. 2000. Norte do Paraná: histórias e fantasmagorias. Curitiba: Aos Quatro Ventos.

Abstract: This article analyzes from a parish in the northern region of Paraná as Catholic actors develop from the afro mass spaces of struggle and confrontation to racism in Brazil. In spite of resistance by the clergy and many faithful, the formulation of this ritual seeks to bring 
to the Catholics the awareness of the reality in which the black lives in Brazil even today, by occupying subaltern positions in various spheres of society. Although there are limits to achieving this goal, the Afro Mass demonstrates a concrete element of the continuity of Liberation Theology today.

Keywords: Afro mass; Catholicisms; Racism; Liberation theology; Religion and politics.

Recebido em outubro de 2017. Aprovado em abril de 2018. 